\title{
Avian mortality from power lines: a morphologic approach of a species-specific mortality
}

\author{
Guyonne F.E. Janss* \\ Department of Applied Biology, Estación Biológica de Doñana, CSIC, Avda de Maria Luisa s/n, Pabellón del Perú, 41013 Seville, Spain
}

\begin{abstract}
Avian mortality from power lines is a species-specific mortality which affects several vulnerable and endangered species. Identifying the characteristics of species at risk of power line mortality can help solve this conservation problem. The relative abundance of bird species near power lines was compared with records of electrocution and collision casualties from these power lines to identify species-specific death risk as determined by wing morphology. Generally, collision victims were "poor" fliers, while electrocution victims were birds of prey, ravens and thermal soarers. Bird species were categorised by wing morphology and risk of either collision or electrocution. Three categories were identified: species with a high risk of collision, species with a high risk of electrocution and a third mixed group, susceptible to both these causes of death. The variables, weight, wing length, total length and tail length classified $88.6 \%$ of the species correctly in these three categories when used in a discriminant analysis. The classification can be used in a predictive model to identify species susceptible to power line mortality. The third mixed group warrants special attention from a conservation point of view because risk is not easily identified and depends on specific behaviour and local circumstances.
\end{abstract}

Keywords: Bird species; Collision; Electrocution; Flight; Power line

\section{Introduction}

Power line mortality is a conservation problem for many bird species, especially those in a vulnerable situation (e.g. Fiedler and Wissner, 1980; Crivelli et al., 1988; Ferrer and Hiraldo, 1991). Although measures are being taken in many countries to mitigate this cause of death, in others the power line grid is still growing and implanted in areas where the impact on the environment is unknown (e.g. Bevanger, 1994, 1998). The coexistence of birds and power lines would be enhanced by a more general approach to this conservation issue. To date many factors related to mortality rate have been identified, yet the identification of morphological and ecological characteristics of the victims has received little attention (Bevanger, 1998).

The number of collisions of birds with power lines does not seem to be related to the flight frequency over a power line (Rusz et al., 1986). A bird's flight performance has been shown to be one of the most important

\footnotetext{
* Fax: + 34-95-4621125.

E-mail address: guyonne@ebd.csic.es (G.F.E. Janss).
}

factors determining the chances of collision with a power line (Bevanger, 1994, 1998; Savereno et al., 1996). General descriptions given to potential collision casualties are "poor fliers" (such as ducks), "heavy birds" (such as swans and cranes), and flock-formers (Bevanger, 1994). Power line designs have been suggested to be related to the possibility of collision accidents, but there are no data available to support this hypothesis. For example, Janss and Ferrer (1998) did not find differences in collision mortality between three power lines with different designs.

On the other hand, there is good evidence that the design of power lines and pylons are important in determining the risk of death from electrocution (e.g. Haas, 1980; Olendorff et al., 1981; Ferrer et al., 1991). On non-conductive, wooden pylons the victims are mostly described as "large raptors" (i.e. those species able to bridge the gap between two conductors) (Olendorff et al., 1981; APLIC, 1996) whereas on metal pylons birds as small as Spanish starlings (Sturnus unicolor) have been electrocuted (Negro, 1987). This explains the wide variety of species reported in studies on bird electrocution on metal pylons, which are mainly used in 
Europe, such as medium and small raptors (e.g. Buteo buteo, Falco tinnunculus), corvids, (e.g. Corvus corax, Pica pica) and storks (Ciconia ciconia) (for a review, see Bevanger, 1998).

Recently, Bevanger (1998) has made a first attempt to explain avian mortality from power lines by wing morphology. A clearer image of bird species involved in power line accidents is important for tackling this conservation problem. I aimed to classify birds by species-specific risk of power line mortality comparing species' abundance with records of mortality and to explain this classification by wing morphology and body measurements using a discriminant analysis.

\section{Methods}

\subsection{Surveys to determine collision risk}

Three different power line sections were studied in the province of Cáceres (Extremadura, central-west Spain). Section A (ca. $4 \mathrm{~km}$ ) was situated in a mainly cultivated area with scrub, oak (Quercus sp.) savannah and cereal cultivation. Section B (ca. $8 \mathrm{~km})$ was situated in a Mediterranean holm oak wood (Quercus ilex). Section C (ca. $4 \mathrm{~km}$ ) crossed a cultivated area used for cattlegrazing and for cereal cultivation forming a steppe-like habitat. By including several habitat types, a wide range of species could be expected to be included in the analysis.

To determine the composition of the local bird community, bird observation surveys were conducted during spring, summer, autumn and winter (Sections A and B, 1991-1992, Section C 1992-1993). In Sections A and B bird counts were made over $72 \mathrm{~h}$, and in Section C over $68 \mathrm{~h}$. Observations were done from fixed points, $200 \mathrm{~m}$ from the power lines. An observer surveyed about 500 $\mathrm{m}$ of power line at a time. During a survey, the number of each species of birds that crossed the power line was recorded. All birds smaller than a turtle dove (Streptopelia turtur) were omitted from analysis. These were likely to be underestimated, as small dead birds are difficult to detect under a power line and have a higher disappearance rate (e.g. Renssen et al., 1975). Relative bird abundance was weighted per season when count efforts were not equal. Therefore, bird abundance was first averaged per season and the mean values were used to calculate the relative abundance of each species during a year.

Seven 2-month surveys for collision casualties were conducted (December 1991 to January 1992) in Sections $\mathrm{A}$ and B. At Section C four 2-month surveys were conducted from August 1992 to March 1993 and another four surveys were conducted monthly from July until October 1993. During the surveys, a zone of ca. $75 \mathrm{~m}$ wide centred along the power line was covered. More than $75 \%$ of the casualties were detected within $20 \mathrm{~m}$ of the power line. All bird remains detected were considered to be collision victims and removed from the transect area to prevent duplication of data on subsequent searches.

Once the classification of bird groups based on risk of power line mortality was made, red-legged partridge (Alectoris rufa), domestic dove (Columba livia domestica) and stone curlew (Burhinus oedicnemus) were added to the species identified during the field studies to improve species diversity in the analysis. These were collision victims recorded by Alonso et al. (1994) in a nearby study area.

\subsection{Surveys to determine electrocution risk}

In south-west Spain, six different areas were selected, three in Andalusia and three in Extremadura region. Two study areas in Andalusia (provinces of Huelva and Cádiz) were predominantly cultivated areas with dispersed oak trees ("dehesa"; Quercus sp.). The remaining area in Andalusia surrounded the Doñana National Park (Ferrer et al., 1991) situated in the south of the provinces of Huelva and Seville, near the Atlantic coast. Habitats dominating this area were marshes, Mediterranean scrubland (Pistacia lentiscus), cork oak forest (Quercus suber), and pine plantations (Pinus pinea). In Extremadura region the areas were situated in the Sierra de San Pedro (Badajoz province) and Monfragüe Natural Park (Cáceres province). Here the landscape was more mountainous with rocky cliffs, Mediterranean scrubland and forests (Quercus ilex), and oak savannah ("dehesa"). The sixth area, located near the city of Cáceres, was a valley partly covered by oak trees and used for extensive agriculture (cattle grazing, grain plantation) forming a steppe-like habitat.

In this more extended study area, road surveys were conducted by two people driving along roads in the proximity of the power lines under study to calculate the relative abundance of diurnal raptors, ravens ( $\mathrm{Cor}$ vus corax) and storks (Ciconia ciconia). These were a priori the most susceptible species to electrocution mortality (e.g. Haas, 1980). The car drove at a constant speed of $40 \mathrm{~km} / \mathrm{h}$. A total of $3464 \mathrm{~km}$ were surveyed, $1833 \mathrm{~km}$ in spring and $1631 \mathrm{~km}$ in autumn. Relative abundance of species was weighted by survey efforts applied in both seasons. Therefore, abundance was first averaged per season and the mean values were used to calculate the relative abundance during a year.

One mortality survey was conducted on 6392 power poles during September 1990-November 1991. Six more surveys were conducted on 2638 power poles during November 1991-November 1992. The base of each pole was checked for casualties within a $10-\mathrm{m}$ radius. The dead raptors, ravens and white storks collected were used to assess the risk of electrocution. Birds found were checked for burns on the primaries, talons or beak and 
removed from the area to prevent double counts in subsequent surveys.

\subsection{Data analysis}

Species were grouped by wing morphology as defined by Rayner (1988) and by their risk of collision and electrocution mortality. Rayner (1988) classified species by wing loading (i.e. ratio of weight to wing area) and aspect ratio (i.e. ratio of wingspan squared to wing area). The difference between their recorded abundance flying near power lines and their numbers of victims of electrocution or collision mortality was used to evaluate the risk of power line mortality. Large values of this difference indicated low risk, and small values high risk of mortality. The term "risk" in this study is used as a synonym for "chance or probability of an accident each time a bird contacts a power line", and "risk exposure" stands for "the number of times a bird contacts a power line per unit of time".

Average measurements for total bird length (beak to tail), wing length, weight and tail length for all species recorded were taken from Cramp and Simmons (1977, 1980, 1982), Cramp (1985) and Cramp and Perrins (1994). Discriminant function analysis was used (standard; cut-value $P=0.50$; Tabachnick and Fidell, 1996) to distinguish the groups identified with similar risk of power line mortality and wing morphology. All variables except tail length were natural log-transformed to obtain a normal distribution.

\section{Results}

\subsection{Power line victims}

Thirty-seven species $(n=2636)$ of birds crossed the power line and nine species $(n=52)$ were collision victims. Great bustard (Otis tarda), little bustard (Tetrax tetrax) and common crane (Grus grus) had the highest records for collision casualties (Table 1). Both great bustard and little bustard, "poor" fliers according to Rayner's classification (1988), were identified as having a high probability to collide with a power line if encountered. Common cranes showed a smaller chance of collision, but because of their high numbers flying over power lines they suffered high mortality (Table 1). Wood pigeon (Columba palumbus), mallard (Anas platyrhynchos) and moorhen (Gallinula chloropus) were also identified as more susceptible than common cranes but less so than "poor" fliers (Table 1). Thermal soarers, represented by griffon vulture (Gyps fulvus), were less frequent in collision records than in flight records, yet were recorded among collision victims. Lower risk species included predators, such as kites (Milvus spp.) and harriers (Circus spp.), none of which were recorded in the mortality surveys.
Twenty-one species of birds $(n=3797)$ were recorded during the road surveys of which 13 were electrocution victims $(n=471)$. Common buzzard (Buteo buteo) and raven were the most frequently electrocuted (total $60.3 \%$ ), while griffon vulture, white stork and black kite (Milvus migrans) were the most abundant species in the road surveys (total $61.6 \%$; Table 1 ). Soarers had the lowest risk of electrocution.

\subsection{Classification by body measurements}

Thermal soarers (griffon vulture, white stork) both appeared in collision and electrocution records with relatively low frequency, while buzzard and hawk species were especially susceptible to electrocution but not to collision mortality. This seemed to justify a separation of soarers with wings of lower aspect ratio from those with wings with higher aspect ratio. Using the symmetry of the circular relation of aspect ratio and wing loading three groups were identified. Generally, electrocution victims were species with low loading and "average" aspect ratio. Collision victims were birds with high loading and average aspect ratio. The remaining species formed a "mixed" group with varying aspect values and average loading values, showing lower susceptibility to both electrocution and collision.

All 41 species (Table 1) were assigned to one of these three groups, adding three species of collision victims recorded by Alonso et al. (1994). A significant discriminant model was obtained when using length, weight, wing and tail length for distinguishing these three groups $\left(F_{(8,76)}=8.46, P<0.0001\right)$, obtaining a $88.6 \%$ of correct classification of species (22 out of 23 among electrocution victims, all eight collision species, and nine out of 13 species located in the "mixed" group; Fig 1).

Means of canonical variables were highest for the electrocution group and lowest for the collision group, while the values of the "mixed" group were intermediate (Table 2). The discriminant function classified "long" birds with low weights, and large tail and wings (Function 1; Tables 2 and 3) in the electrocution group, although for very large birds this value will decrease (Function 2; Tables 2 and 3) and such species will enter in the mixed group. For collision victims the opposite was observed: "short" birds with large weights, short wings and tails belong to the collision group (Function 1; Tables 2 and 3), while the discriminant value of very small birds is higher (Function 2; Tables 2 and 3), making them belong to the mixed group.

\section{Discussion}

The body measurements used in the analysis provided a significant discriminant model which separated bird species at risk of collision from those at risk of electrocution. 
Table 1

Bird species found dead by electrocution (E) and collision (C), total numbers of birds recorded by the abundance surveys at the respective power lines, the difference between relative abundance and relative casualty numbers (victims - V) in south-west Spain between 1991 and 1993, and grouping of species according to mainly electrocution victims, mainly collision victims and species vulnerable to both (mixed - M)

\begin{tabular}{|c|c|c|c|c|c|c|c|}
\hline \multirow[b]{2}{*}{ Species } & \multicolumn{2}{|c|}{ Casualties } & \multicolumn{2}{|c|}{ Abundance } & \multicolumn{2}{|c|}{ Difference $\% \mathrm{~A}-\% \mathrm{~V}$} & \multirow[t]{2}{*}{ Group } \\
\hline & $\mathrm{E}$ & $\mathrm{C}$ & $\mathrm{E}^{\mathrm{a}}$ & $\mathrm{C}^{\mathrm{b}}$ & $\mathrm{E}$ & $\mathrm{C}$ & \\
\hline Ardea cinerea (grey heron) & & & & 2 & & 0.1 & $\mathrm{E}^{\mathrm{c}}$ \\
\hline Bubulcus ibis (cattle egret) & & & & 3 & & 0.1 & $\mathrm{E}^{\mathrm{c}}$ \\
\hline Egretta garzetta (little egret) & & & & 6 & & 0.2 & $\mathrm{E}^{\mathrm{c}}$ \\
\hline Ciconia ciconia (white stork) & 36 & 5 & 648 & 42 & 9.5 & -7.8 & M \\
\hline Ciconia nigra (black stork) & & & & 2 & & 0.1 & $\mathrm{M}^{\mathrm{c}}$ \\
\hline Anas platyrhynchos (mallard) & & 3 & & 2 & & -5.7 & $\mathrm{C}$ \\
\hline Milvus migrans (black kite) & 45 & & 631 & 26 & 7.0 & 1.0 & $\mathrm{E}$ \\
\hline Milvus milvus (red kite) & 45 & & 446 & 61 & 2.1 & 2.3 & $\mathrm{E}$ \\
\hline Neophron percnopterus (Egyptian vulture) & & & 16 & 75 & 0.4 & 2.9 & M \\
\hline Aegypius monachus (black vulture) & 1 & & 217 & 4 & 0.1 & 5.5 & $\mathrm{M}$ \\
\hline Gyps fulvus (griffon vulture) & 5 & 1 & 1060 & 283 & 26.8 & 8.8 & M \\
\hline Circus aeruginosus (marsh harrier) & & & 65 & 4 & 1.7 & 1.1 & $\mathrm{E}^{\mathrm{c}}$ \\
\hline Circus cyaneus (hen harrier) & & & & 11 & & 0.4 & $\mathrm{E}^{\mathrm{c}}$ \\
\hline Circus pygargus (Montagu's harrier) & & & 14 & 28 & 0.4 & 0.2 & $\mathrm{E}^{\mathrm{c}}$ \\
\hline Accipiter gentilis (goshawk) & 5 & & 3 & & -0.3 & & $\mathrm{E}$ \\
\hline Accipiter nisus (sparrowhawk) & & & 3 & & 0.8 & & $\mathrm{E}^{\mathrm{c}}$ \\
\hline Buteo buteo (common buzzard) & 167 & & 195 & 37 & -30.4 & 1.4 & $\mathrm{E}$ \\
\hline Aquila adalberti (Spanish imperial eagle) & 4 & & 13 & & -0.6 & & $\mathrm{M}$ \\
\hline Aquila chrysaetos (golden eagle) & & & 9 & 17 & 0.2 & 0.7 & $\mathrm{M}^{\mathrm{c}}$ \\
\hline Hieraaetus fasciatus (Bonelli's eagle) & 17 & & 6 & 13 & -3.4 & 0.5 & M \\
\hline Hieraaetus pennatus (booted eagle) & & & 24 & 13 & 0.6 & 0.5 & $\mathrm{M}^{\mathrm{c}}$ \\
\hline Circaetus gallicus (short-toed eagle) & 11 & & 35 & 28 & -1.4 & 1.1 & $\mathrm{E}$ \\
\hline Pandion haliaetus (osprey) & & & 6 & & 0.2 & & $\mathrm{M}^{\mathrm{c}}$ \\
\hline Falco naumanni (lesser kestrel) & & & 81 & 39 & 2.3 & 1.5 & $\mathrm{E}^{\mathrm{c}}$ \\
\hline Falco peregrinus (peregrine falcon) & 4 & & 12 & 1 & -0.6 & 0.0 & $\mathrm{E}$ \\
\hline Falco tinnunculus (common kestrel) & 14 & & 275 & 39 & 4.2 & 1.5 & $\mathrm{E}$ \\
\hline Gallinula chloropus (moorhen) & & 1 & & & & -1.9 & $\mathrm{C}^{\mathrm{c}}$ \\
\hline Grus grus (common crane) & & 8 & & 1216 & & 30.7 & $\mathrm{M}$ \\
\hline Otis tarda (great bustard) & & 16 & & 7 & & -30.5 & $\mathrm{C}$ \\
\hline Tetrax tetrax (little bustard) & & 10 & & & & -19.2 & $\mathrm{C}$ \\
\hline Himantopus himantopus (black-winged stilt) & & & & 3 & & 0.1 & $\mathrm{M}^{\mathrm{c}}$ \\
\hline Vanellus vanellus (lapwing) & & 1 & & 84 & & 1.3 & M \\
\hline Columba palumbus (wood pigeon) & & 7 & & 293 & & -2.3 & $\mathrm{C}$ \\
\hline Streptopelia turtur (turtle dove) & & & & 6 & & 0.2 & $\mathrm{M}^{\mathrm{c}}$ \\
\hline Clamator glandarius (great spotted cuckoo) & & & & 7 & & 0.3 & $\mathrm{E}^{\mathrm{c}}$ \\
\hline Upupa epops (hoopoe) & & & & 1 & & 0.0 & $\mathrm{E}^{\mathrm{c}}$ \\
\hline Corvus corax (common raven) & 117 & & 38 & 42 & -23.8 & 1.6 & $\mathrm{E}$ \\
\hline Corvus monedula (jackdaw) & & & & 36 & & 1.4 & $\mathrm{E}^{\mathrm{c}}$ \\
\hline Cyanopica cyanus (azure-winged magpie) & & & & 35 & & 1.4 & $\mathrm{E}^{\mathrm{c}}$ \\
\hline Garrulus glandarius (jay) & & & & 3 & & 0.1 & $\mathrm{E}^{\mathrm{c}}$ \\
\hline Pica pica (magpie) & & & & 167 & & 6.3 & $\mathrm{E}^{\mathrm{c}}$ \\
\hline Total & 467 & 52 & 3797 & 2662 & & & \\
\hline
\end{tabular}

${ }^{a}$ Total number of birds recorded during road surveys done in the electrocution study area.

b Total number of birds recorded crossing the power lines surveyed for collision casualties.

c Species with insufficient data were classified according to species with similar wing morphology.

The main difference between these two groups seemed to be the wing loading value, coinciding with Bevanger's review (Bevanger, 1998). The classification of the species in this study coincides with other records of species recorded as power line victims (Bevanger, 1998), which suggests that the discriminant model could be a useful tool to identify the potential risk of any species to power line mortality. With regard to the conservation of species, potential or theoretical risk is an important value, although it should be combined with a risk exposure value (e.g. number of crossings over a power line, perching frequency, etc.). For example, in Spain, the common crane might actually suffer a higher rate of mortality due to frequent flight movements than the common bustard, which has mainly terrestrial habits, in spite of the crane's better flight capacities.

From the classification obtained we should not infer that low wing loading increases the risk of electrocution. 


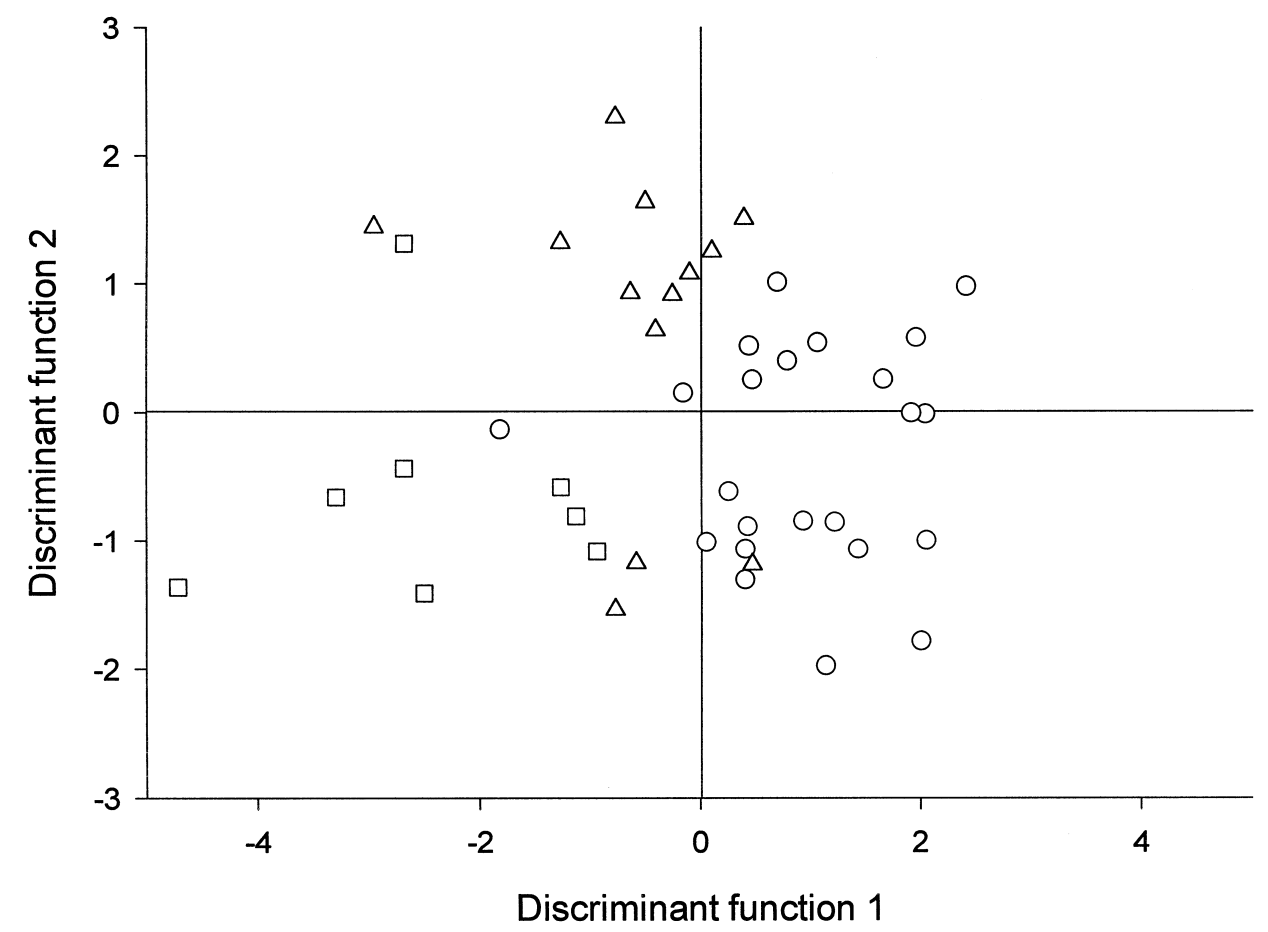

Fig. 1. Visual representation of the results of the discriminant functions which classified bird species in 3 groups with different risk of power line mortality. Squares are collision victims, circles are electrocution victims and triangles are species susceptible to both causes of mortality.

Low wing loading is associated with high manoeuvrability in flight, typical of some birds of prey, which are at risk of electrocution due to this behaviour. It should be stressed that birds with very low wing loading (e.g. harriers) are less exposed to electrocution risk, because they use aerial hunting techniques and rarely perch

\section{Table 2}

Mean canonical values of discriminant Function 1 and 2 that classify the three groups of bird species with different risk values for electrocution and collision with power lines, by length, wing, tail and weight measures

\begin{tabular}{llc}
\hline & \multicolumn{2}{l}{ Mean canonical value } \\
\cline { 2 - 3 } Group & Function 1 & Function 2 \\
\hline Electrocution victims & 1.05 & -0.25 \\
Collision victims & -2.33 & -0.57 \\
Mixed & -0.43 & 0.80 \\
\hline
\end{tabular}

(APLIC, 1996). Other local factors, not related to species, might also explain differences in mortality rates. Bad weather conditions and poor visibility increase the possibility of collision and electrocution accidents (Renssen et al., 1975; APLIC, 1994, 1996). This could result in different mortality rates for populations of the same species inhabiting different areas. Furthermore differences can exist between individuals. For example, young birds have relatively little flight experience and weakened birds might have reduced reaction capability (Mathiasson, 1993; APLIC, 1994, 1996; Henderson et al., 1996), while familiarity with the area could reduce collision mortality (Anderson, 1978; Bevanger, 1994).

Although I could separate collision victims from electrocution victims by body measurements related to flight capacities, a "mixed" group remained, which could not be distinguished by body measurements but

Table 3

Raw and standardised (in parentheses) coefficients of parameters in the two discriminant functions which discriminated species with high collision risk (low negative values) from species with high electrocution risk (high positive values) and a mixed group at an intermediate position

\begin{tabular}{|c|c|c|c|c|c|}
\hline \multirow[b]{2}{*}{ Variable } & \multicolumn{2}{|l|}{ Coefficients } & \multicolumn{3}{|c|}{ Statistics } \\
\hline & Function 1 & Function 2 & $F_{(2,38)}$ & $P$ & $r^{2}$ \\
\hline Log (length) & $3.74(1.40)$ & $0.22(0.08)$ & 4.07 & 0.025 & 0.86 \\
\hline Log (weight) & $-3.40(-3.74)$ & $0.26(0.28)$ & 25.41 & $<0.001$ & 0.94 \\
\hline Log (wing) & $4.63(1.91)$ & $1.12(0.46)$ & 6.50 & 0.004 & 0.89 \\
\hline Tail & $0.08(0.59)$ & $0.03(0.24)$ & 2.19 & 0.126 & 0.56 \\
\hline Constant & -10.20 & -7.12 & & & \\
\hline
\end{tabular}


which did have different mortality expectations. In this case, power line mortality seems to depend on the particular behaviour of each species. Risk exposure and perch behaviour, both related to roosting, feeding and breeding habits, are key factors. This is best illustrated by comparing cranes, storks, eagles and vultures, four bird groups with similar wing morphology and presumably, therefore, similar risk values to power line mortality, yet with different mortality rates.

Eagles were rarely reported as collision victims probably due to both low exposure (i.e. low number of crossings a day) and their solitary habits. Flying in flocks (exhibited by cranes, storks and vultures) increases the possibility of collision because those birds at the rear of the flock are relatively unaware of obstacles (APLIC, 1994). Eagles frequently use pylons for roosting, feeding and hunting, which results in a significant electrocution mortality for several species such as the Spanish imperial eagle (Aquila adalberti) (Ferrer and Hiraldo, 1991). Griffon vultures rarely perch on power poles in Spain (out of $>300$ observations of birds perched on pylons, I observed only one griffon vulture in the study area), which can explain the few incidences of this species as electrocution victim. In contrast, in South Africa, roosting on power poles by Cape vultures (Gyps coprotheres) caused widespread electrocution to this species (Hobbs and Ledger, 1986). My records suggest that the black vulture (Aegypius monachus) (much rarer than the griffon vulture in Spain; Donázar, 1993) is more at risk of electrocution than the griffon vulture. The black vulture breeds in trees, while the griffon vulture breeds on cliffs (Donazar, 1993), which might cause different perching behaviour on pylons. The griffon vulture was also low amongst collision victims. It is probably less exposed to collision risk than storks and cranes since it spends most of the time soaring at high altitude and only descends when carrion is detected. Cranes, ground breeders and feeders are not electrocution victims since they do not perch on poles, but they are often exposed to risk by daily flock movements between feeding, breeding and roosting areas. Storks are common victims of both causes of death. They have similar feeding habits as cranes, but are not ground breeders. Perching on elevated sites, such as pylons, for both breeding and roosting is a common behaviour in white storks.

Overall, this "mixed" group warrants special attention from a conservation perspective, as they all seem to be at risk of collision. The extent to which this is a problem depends, for each species, on the number of hours in flight near power lines, social behaviour of the species (e.g. flock forming), and local factors (such as local weather). Some of these species are also at risk of electrocution, which increases the potential impact of power lines on their populations. The identification of the power line mortality affecting a species is important (collision, electrocution or both), since different mortality characteristics require different mitigation measures.

Electrocution mortality can be solved by pylons with dimensions which no bird is able to bridge with its body (e.g. electrocution can not occur on transmission towers) and by insulation (APLIC, 1996; Janss and Ferrer, 1999). Power line collisions can be reduced, although not eradicated (e.g. APLIC, 1994; Alonso et al, 1994; Brown and Drewien, 1995; Janss and Ferrer, 1998). The most frequently used measure is wire-marking, which alerts birds to the presence of power lines and provides them with more time to avoid the collision. Renssen et al. (1975) found that lowering the number of cable levels in the power lines reduced power line collisions because only a small change in flight altitude was needed to avoid the cables on one level. The influence of the power line design on collision rates, however, is little studied. The use of raptor models to scare off birds from power lines has not produced encouraging results (Janss et al., 1999). Because mitigation measures only reduce collision mortality, but do not solve it, adequate route planning of power lines is especially important in this case. Power lines are not the only hazards for bird conservation; other human structures in natural areas provide "unnatural" obstacles for birds, such as wind turbines and guide wires of communication antennas (Orloff and Flannery, 1993; Musters et al. 1996). This suggests that a further understanding of birds' flight behaviour could be important to deal with the collision problem.

\section{Acknowledgements}

I thank E. Migens, J. Cepeda and J. Sánchez for help in the field. J. Negro, M. Ferrer and E. Revilla made useful comments on an earlier draft of the paper. J. Simons, an anonymous referee and B.N.K. Davis improved the clarity of the manuscript and provided useful points for discussion. T. Aplin and E. Revilla kindly revised the English. The consultancy Estudios y Proyectos CLAVE provided the facilities to execute this project and the Estación Biológica de Doñana to write this manuscript. The study was financed by three Spanish Utility Companies: SEVILLANA de Electricidad, IBERDROLA and RED ELÉCTRICA.

\section{References}

Alonso, J.C., Alonso, J.A., Muńoz-Pulido, R, 1994. Mitigation of bird collisions with transmission lines through groundwire marking. Biological Conservation 67, 129-134.

Avian Power Line Interaction Committee (APLIC), 1994. Mitigating Bird Collisions with Power Lines: The State of the Art in 1994 Washington, DC, Edison Electric Institute. 
Avian Power Line Interaction Committee (APLIC), 1996. Suggested Practices for Raptor Protection on Power Lines: The State of the Art in 1996. Edison Electric Institute, Washington, DC.

Anderson, W.L., 1978. Waterfowl collisions with power lines at a coalfired power plant. Wildlife Society Bulletin 6, 77-83.

Bevanger, K., 1994. Bird interactions with utility structures: collision and electrocution, causes and mitigation measures. Ibis 136, 412-425.

Bevanger, K., 1998. Biological and conservation aspects of bird mortality caused by electricity power lines: a review. Biological Conservation $86,67-76$.

Brown, W.M., Drewien, R.C, 1995. Evaluation of two power lines markers to reduce crane and waterfowl collision mortality. Wildlife Society Bulletin 23 (2), 217-227.

Cramp, S., (Ed.), 1985. Handbook of the Birds of Europe, the Middle East and North Africa; The Birds of the Western Paleartic, vol. IV. Oxford University Press, Oxford.

Cramp, S., Perrins, C.M., (Eds.), 1994. Handbook of the Birds of Europe, the Middle East and North Africa; The Birds of the Western Paleartic, vol. VIII. Oxford University Press, Oxford.

Cramp, S., Simmons, K.E.L., (Eds.), 1977. Handbook of the Birds of Europe, the Middle East and North Africa; The Birds of the Western Paleartic, vol. I. Oxford University Press, Oxford.

Cramp, S., Simmons, K.E.L., (Eds.). 1980. Handbook of the Birds of Europe, the Middle East and North Africa; The Birds of the Western Paleartic, vol. II. Oxford University Press, Oxford.

Cramp, S., Simmons, K.E.L., (Eds.) 1982. Handbook of the Birds of Europe, the Middle East and North Africa; The Birds of the Western Paleartic, vol. III. Oxford University Press, Oxford.

Crivelli, A.J., Jerrentrup, H., Mitchev, T., 1988. Electric power lines: a cause of mortality in Pelecanus crispus Bruch, a world endangered bird species. Col. Waterbirds 11, 301-305.

Donázar, J.A., 1993. Los buitres ibéricos. Biología y Conservación. J. M. Reyero, Madrid.

Ferrer, M., De La Riva, M., Castroviejo, J., 1991. Electrocution of raptors on power lines in Southern Spain. Journal of Field Ornithology 62, 54-69.

Ferrer, M., Hiraldo, F., 1991. Evaluation of management techniques for the Spanish imperial eagle. Wildlife Society Bulletin 19 (4), 436-442.

Fiedler, G., Wissner, A., 1980. Freileitungen als tödliche Gefahr für Weißstörche (Ciconia ciconia). Ökologie der Vögel 2, 59-109.

Haas, D., 1980. Gefährdung unserer Großvögel durch Stromschlageine Dokumentation. Ökologie der Vögel 2, 7-57.

Henderson, I.G., Langston, R.H.W., Clark, N., 1996. The response of common terns Sterna hirundo to power lines: an assessment of risk in relation to breeding commitment, age and wind speed. Biological Conservation 77, 185-192.

Hobbs, J.C., Ledger, J.A., 1986. Powerlines, birdlife and the golden mean. Fauna \& Flora 44, 23-27.

Janss, G.F.E., Ferrer, M., 1998. Rate of bird collision with power lines: effects of conductor-marking and static wire-marking. Journal of Field Ornithology 69, 8-17.

Janss, G.F.E., Ferrer, M., 1999. Mitigation of raptor electrocution on steel power poles. Wildlife Society Bulletin 27, 263-273.

Janss, G.F.E., Lazo, A., Ferrer, M., 1999. Use of raptor models to reduce avian collisions with powerlines. Journal of Raptor Research $33,154-159$.

Mathiasson, S., 1993. Mute Swans, Cygnus olor, killed from collision with electrical wires, a study of two situations in Sweden. Environmental Pollution 80, 239-246.

Musters, C.J.M., Noordervliet, M.A.W., Keurs, W.J., 1996. Bird casualties caused by a wind energy project in an estuary. Bird Study $43,123-126$.

Negro, J.J., 1987. Adaptación de los tendidos eléctricos al entorno. Monografías de Alytes, núm. 1. ADENEX, Mérida.

Olendorff, R.R., Miller, A.D., Lehman, R.N., 1981. Suggested practices for raptor protection on power lines: The state of the art in 1981. Raptor Research Report No. 4. Raptor Research Foundation. Utah.

Orloff, S. G., Flannery, A. W., 1993. Wind turbine effects on avian activity, habitat use, and mortality in the Altamont pass and Solano county wind resource areas. Avian Interactions with Utility Structures, Miami, Florida, Avian Power Line Interactions Committee, Electric Power Research Institute.

Rayner, J.M.V., 1988. Form and function in avian flight. In: Johnston, R.F. (Ed.), Current Ornithology. Plenum, New York, pp. 1-66, vol. 5 .

Renssen, T.A., Bruin, A., van de Doorn, J.H., Gerritsen, A., Greven, H.C., Kamp, J. et al., 1975. Vogelsterfte in Nederland tengevolge van aanvaringen met hoogspanningslijnen. RIN Arnhem.

Rusz, P.J., Prince, H.H., Rusz, R.D., Dawson, G.A., 1986. Bird collisions with transmission lines near power plant cooling pond. Wildlife Society Bulletin 14, 441-444.

Savereno, A.J., Savereno, L.A., Boettcher, R., Haig, S.M., 1996. Avian behavior and mortality at power lines in coastal South Carolina. Wildlife Society Bulletin 24, 636-648.

Tabachnick, B.G., Fidell, L.S., 1996. Using Multivariate Statistics, 3rd Edition. HarperCollins, New York. 